\title{
STRATEGI MENINGKATKAN KUALITAS PELAYANAN MELALUI DIGITALISASI PRODUK PERBANKAN PADA \\ PT. BANK MANDIRI (PERSERO) Tbk. KANTOR CABANG KARTINI MAKASSAR
}

\author{
Erika Salsanabila Ali \\ Institut Bisnis Dan Keuangan Nitro Makassar \\ Email: esalsanabila45@gmail.com
}

\begin{abstract}
ABSTRAK
Strategi meningkatkan kualitas layanan melalui digitalisasi jasa merupakan suatu strategi yang digunakan suatu perusahaan untuk pengembangan layanan yang berbasisi digital untuk menjawab kebutuhan konsumen yang semakin digital. Demikian juga dengan bisnis perbankan yang terus melakukan inovasi untuk meningkatkan kualitas layanannya. Bagi Perbankan, digitilasi bukanlah sebuah pilihan tetapi menjadi keharusan dan kewajiban. Karena nasabah mengharapkan adanya kecepatan, kemudahan, fleksibilitas, kenyaman dan tersedia layanan 24 jam.
\end{abstract}

Kata Kunci : Strategi, Kualitas Layanan, Digitalisasi

\section{PENDAHULUAN}

Sejak lima tahun terakhir, digitalisasi produk dan layanan keuangan menjadi tuntutan utama bagi industri perbankan untuk memenangkan persaingan. Sesuai bagi pasar generasi milenial yang merupakan 
digital native, sekaligus membuat ekosistem perbankan semakin efektif dan efisien. Untuk menunjang hal tersebut, Bank Mandiri mempunyai Memiliki 3 pilar dalam digital banking. Pertama adalah digitalisasi internal proses, yaitu bagaimana proses di dalam bank mandiri itu untuk siap di era digital. Pilar kedua adalah meoderinisasi E-channel, jadi channel yang sudah ada seperti, ATM, Internet Banking, Mobile Banking, Call Center dan lainnya dilakukan modenisasi sesuai era digital saat ini. Pilar ketiga adalah leverage digital ecosystem, baik itu berkolaborasi dengan marketplace maupun e-commerce. Namun, tiga pilar ini tetap berada dalam balutan risk management dan security IT yang bagus.

Digitalisasi yang dilakukan bank Mandri diantaranya dengan berbagai produk digital yang dikembangkan oleh bank Mandiri yaitu : Layanan E-Banking/E-Channel ( Livin' by Mandiri, Mandiri E-Money, Link Aja, Mandiri SMS, Mandiri EDC, Mandiri Internet Bisnis, dan lain sebagainya).

Dengan digitalisasi produk perbankan semakin berkembang maka kualitas pelayanan semakin baik. Menurut Daga, R (2003) Kualitas layanan merupakan suatu pernyataan tentang sikap, hubungan yang dihasilkan dari perbandingan antara ekspektasi (harapan) dengan kinerja (hasil). Dimana dalam menunjang pengelolaan aktivitas perbankan maka perlu adanya tingkat pelayanan nasabah, 
sebab dengan adanya tingkat pelayanan nasabah maka akan memberikan kepuasan bagi nasabah.

\section{PENDAHULUAN}

\section{Strategi}

Strategi adalah proses penentuan rencana para pemimpin puncak yang berfokus pada tujuan jangka panjang organisasi, disertai penyusunan suatu cara atau upaya bagaimana agar tujuan tersebut dapat dicapai.

Menurut Tjiptono (2006:3) istilah strategi berasal dari bahasa Yunani yaitu strategia yang artinya seni atau ilmu untuk menjadi seorang jendral. Strategi juga bisa diartikan suatu rencana untuk pembagian dan penggunaan kekuatan militer pada daerah - daerah tertentu untuk mencapai tujuan tertentu.

Menurut Menurut Pearce II dan Robinson (2008:2), strategi adalah rencana berskala besar, dengan orientasi masa depan, guna berinteraksi dengan kondisi persaingan untuk mencapai tujuan.

Menurut Rangkuti (2013:183) berpendapat bahwa strategi adalah perencanaan induk yang komprehensif, yang menjelaskan bagaimana perusahaan akan mencapai semua tujuan yang telah di tetapkan berdasarkan misi yang telah di tetapkan sebelumnya. 
Dari definisi tersebut penulis menyimpulkan bahwa pengertian strategi adalah hal hal yang perusahaan ingin lakukan untuk mencapai suatu tujuan yang telah di tetapkan sebelumnya.

Menurut pandangan Dan Schendel dan Charles Hofer, Higgins (1985) menjelaskan adanya empat tingkatan strategi. Keseluruhannya disebut Master Strategy, yaitu:

1) Enterprise Strategy (strategi perusahaan)

Strategi ini berkaitan dengan respons masyarakat. Setiap organisasi mempunyai hubungan dengan masyarakat. Masyarakat adalah kelompok yang berada di luar organisasi yang tidak dapat dikontrol. Di dalam masyarakat yang tidak terkendali itu, ada pemerintah dan berbagai kelompok lain seperti kelompok penekan, kelompok politik dan kelompok sosial lainnya.

2) Coorporate Strategy (strategi korporasi)

Strategi ini berkaitan dengan misi organisasi, sehingga sering disebut Grand Strategy yang meliputi bidang yang digeluti oleh suatu organisasi. Pertanyaan apa yang menjadi bisnis atau urusan kita dan bagaimana kita mengendalikan bisnis itu, tidak sematamata untuk dijawab oleh organisasi bisnis, tetapi juga oleh setiap organisasi pemerintahan dan organisasi nonprofit.

3) Business Strategy (strategi bisnis)

Strategi pada tingkat ini menjabarkan bagaimana merebut pasaran di tengah masyarakat. Bagaimana menempatkan 
organisasi di hati para penguasa, para pengusaha, para investor dan sebagainya. Semua itu dimaksudkan untuk dapat memperoleh keuntungan - keuntungan strategi yang sekaligus mampu menunjang berkembangnya organisasi ke tingkat yang lebih baik.

4) Functional Strategy (strategi fungsional)

Merupakan strategi yang terjadi di level fungsional seperti, operasional, pemasaran, keuangan, sumber daya manusia. Riset dan pengembangan dimana strategi ini akan meningkatkan area fungsional perusahaan sehingga mendapat keunggulan bersaing. Strategi ini harus mengacu pada strategi bisnis dan strategi korporasi.Memfokuskan pada memaksimumkan produktivitas sumber daya yang digunakan dalam memberikan value terbaik untuk pemenuhan kebutuhan pelanggan (customer). Strategi fungsional sering juga disebut Value-based-strategy.

\section{Kualitas Pelayanan}

Pengertian kualitas layanan atau kualitas jasa berpusat pada upaya pemenuhan kebutuhan dan keinginan pelanggan serta ketepatan penyampaiannya untuk mengimbangi harapan pelanggan.

Menurut Wyckof (Tjiptono, 2002:59) Kualitas jasa adalah tingkat keunggulan yang diharapkan dan pengendalian atas tingkat keunggulan tersebut untuk memenuhi keinginan pelanggan. 
Menurut Parasuraman (1988:23) Kualitas layanan merupakan refleksi persepsi evaluatif konsumen terhadap pelayanan yang diterima pada suatu waktu tertentu. Kualitas pelayanan ditentukan berdasarkan tingkat pentingnya pada dimensi pelayanan. Menyusun dimensi pokok yang menjadi faktor utama penentu kualitas layanan jasa sebagai berikut.

1) Reliability (Keandalan)

Yaitu kemampuan untuk mewujudkan pelayanan yang dijanjikan dengan handal dan akurat.

2) Responsiveness (Daya tanggap)

Yaitu kemauan untuk membantu para konsumen dengan menyediakan pelayanan yang cepat dan tepat.

3) Assurance (Jaminan)

Yaitu meliputi pengetahuan, kemampuan, dan kesopanan atau kebaikan dari personal serta kemampuan untuk mendapatkan kepercayaan dan keinginan.

4) Empathy (Empati)

Yaitu mencakup menjaga dan memberikan tingkat perhatian secara individu atau pribadi terhadap kebutuhan-kebutuhan konsumen.

5) Tangible (Bukti langsung)

Yaitu meliputi fasilitas fisik, peralatan atau perlengkapan, harga, dan penampilan personal dan material tertulis. 


\section{Digitalisasi}

Digitalisasi adalah proses membuat atau memperbaiki proses bisnis dengan menggunakan teknologi dan data digital. Istilah digitalisasi mengacu pada penggunaan teknologi dan data digital untuk meningkatkan bisnis, pendapatan, dan menciptakan budaya digital. Dalam praktiknya, data digital dijadikan sebagai pendukung utama untuk seluruh proses tersebut. Jika sudah ditahap digitalisasi, perusahaan sudah mampu mengubah proses bisnis menjadi lebih efisien, produktif, dan menguntungkan.

Menurut Kusumah (2001:15), menyatakan bahwa Digitalisasi ialah bagian dari pelestarian yang berupaya untuk menyelamatkan naskahnaskah kuno dengan memanfaatkan teknologi digital seperti soft file,foto digital, microfon, serta mengupayakan baik naskah duplikasinya agar dapat bertahan dalam jangka waktu yang relatif lama.

Digital perbankan adalah bagian dari konteks yang lebih luas untuk pindah ke perbankan online, di mana layanan perbankan disampaikan melalui internet.

Menurut (Skinner, 2014:57) Digital banking merupakan layanan kegiatan perbankan menggunakan sarana elektronik atau digital milik bank, di mana nasabah bank dapat melakukan aktivitas perbankan secara mandiri

Melalui digitalisasi, perbankan bisa menjangkau masyarakat atau pelaku UMKM yang belum menikmati layanan bank. Sebab melalui digitalisasi, 
bank bisa berkolaborasi dengan sektor jasa keuangan lain, seperti financial technology (fintech) peer to peer (P2P) lending, koperasi, pegadaian, perusahaan pembiayaan, lembaga keuangan mikro, marketplace, atau e-commerce yang memiliki jaringan, kemudahan, dan akses lebih luas. Selain itu, digitalisasi perbankan ini memungkinkan perbankan untuk menerbitkan produk nontunai yang memudahkan masyarakat untuk melakukan transaksi jarak jauh. Pada umumnya, produk non tunai perbankan berupa: e-wallet atau rekening digital.

Digitalisasi perbankan ini sangat bermanfaat bagi semua pihak. Adapun manfaat layanan digitalisasi perbankan bagi kita adalah sebagai berikut.

1) Praktis dan Mudah di Akses

Internet mudah diakses dan menjangkau ke seluruh pelosok. Jadi, tidak perlu lagi datang ke bank untuk melakukan transaksi perbankan cukup memanfaatkan jaringan internet di gadget.

2) Menghemat Biaya dan Waktu

Digitalisasi perbankan dinilai dapat menghemat biaya dan waktu. Hemat biaya yang dimaksud tidak perlu mengeluarkan biaya untuk datang ke bank. Selain itu, dapat menghemat waktu karena tidak membutuhkan waktu yang lama saat antri di bank.

3) Ramah Lingkungan

Adanya digitalisasi perbankan ini dinilai ramah lingkungan karena bank dapat menghemat kertas. Hal tersebut karena semua 
transaksi perbankan dilakukan melalui proses digital menggunakan gadget dan akses internet

\section{PENETELITIAN TERDAHULU}

1. Yusuf Rombe (2020) melakukan penelitian dengan judul "Strategi Meningkatkan Kualitas Layanan Melalui Digitaliasi Jasa Perbankan Di PT. Bank Negara Indonesia (Persero) Tbk. Kantor Pusat Jakarta Pusat". Hasil penelitian ini menunjukkan bahwa strategi PT. Bank Negara Indonesia (persero) Tbk. Jakarta Pusat adalah meningkatkan budaya kerja di internal BNI atas perubahan layanan konvensional ke layanan yang terdigitalisasi sehingga $\mathrm{BNI}$ terus dapat tumbuh dan berkembang di era digitalisasi yang persaingannya sangatlah ketat, peningkatan terhadap sistem keamanan dari suatu layanan jasa yang terdigitalisasi untuk menghindari risiko-risiko yang dapat terjadi seperti cyber crime, membuka diri terhadap perubahan yang ada saat ini sehingga tidak terpaku pada sistem yang lama dengan terus mengembangkan layanan jasa kearah digitalisasi, perbaikan koordinasi antar divisi yang ada di BNI agar tercapainya digitalisasi pada BNI yang lebih baik lagi.

2. Wari Sugiana (2018) melakuka penelitian dengan judul "Strategi Meningkatkan Kualitas Pelayanan Melalui Digitalisasi Produk Perbankan Di Bank Bni Syariah Kcp Bulaksumur Yogyakarta”. Hasil penelitian ini menunjukkan bahwa strategi BNI Syariah KCP 
Bulaksumur Yogyakarta mempunyai strategi untuk meningkatkan kualitas pelayanan, yaitu melalui produk layanan berbasis digital seperti Aplikasi Marketing Kit, APRO (Aplikasi Pembukaan Rekening Online), Aplikasi Wakaf Hasanah, Hasanah Personal, Aplikasi YAP! (Your All Payment) dan E-Banking (Electronic Banking). Dari beberapa produk layanan berbasis digital tersebut, ada empat produk layanan yang menjadi ciri khas Bank BNI Syariah, yaitu APRO (Aplikasi Pembukaan Rekening Online), Aplikasi Wakaf Hasanah, Aplikasi Hasanah Personal, Aplikasi YAP! (Your All Payment). Aplikasi tersebut tidak dapat ditemukan di bank-bank lainnya.

\section{KERANGKA PIKIR}

Gambar 2.1

Kerangka Pikir

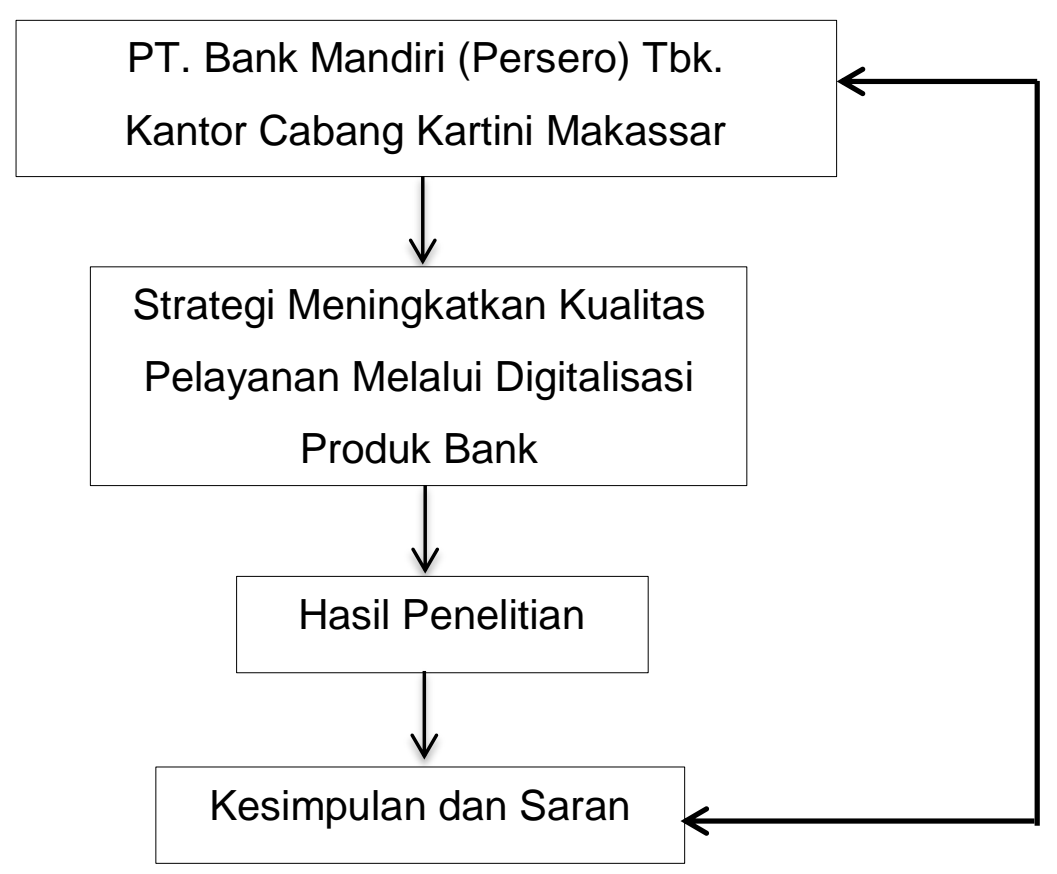


Keterangan :

PT. Bank Mandiri (Persero) Tbk. Kantor Cabang Kartini Makassar merupakan sebuah perusahaan yang bergerak di bidang jasa perbankan, bertujuan meningkatkan kualitas perusahaan dan jumlah nasabah demi kemajuan perusahaan. Salah satu upaya yang dilakukan adalah dengan meningkatkan kualitas pelayanan melalui digitalisasi produk perbankan pada PT. Bank Mandiri (Persero) Tbk. Kantor Cabang Kartini Makassar.

\section{METODE PENELITIAN}

Jenis data yang digunakan dalam penelitian ini adalah data kualitatif, dimana data kualitatif adalah suatu data yang berbentuk data maupun kalimat. Data ini diperoleh dari informasi secara lisan (wawancara).

Sumber data pada penelitian ini berupa data primer yang berasal dari wawancara langsung dan observasi dengan informan peneliti.

Teknik pengumpulan data dilakukan melalui wawancara secara mendalam dengan instrumen yang tidak terstruktur. Lamanya waktu wawancara tidak dibatasi, namun tetap memperhatikan etika dan kondisi informan. Meskipun instrumen wawancara tidak terstruktur, peneliti menyiapkan konsep yang akan ditanyakan, namun dalam prakteknya peneliti akan membuat wawancara mengalir dan berkembang. Teknik 
pengumpulan data non verbal dilakukan dengan melalui observasi dan dokumentasi. Penelitian ini akan dibantu oleh kamera, perekam suara dan catatan harian observasi

\section{KESIMPULAN}

Berdasarakan hasil penelitian, peningkatan kualitas pelayanan dapat melalui digitalisasi produk perbankan, dimana digitalisasi merupakan proses membuat atau memperbaiki proses bisnis dengan menggunakan teknologi dan data digital. Di era saat ini sangat dibutuhkan sistem digital yang dapat mempermudah, untuk itu Bank Mandiri terus berinovasi dalam meningkatkan digital produk perbankan agar kualitas pelayanan kepada nasabah semakin baik. Karena pelayanan nasabah sangat berperan dalam memajukan perusahaan dan bersaing dengan perbankan lainnya.

\section{DAFTAR PUSTKA}

Daga, R. 2019 “Pengaruh Kualitas Layanan dan Kualitas Produk Tabunganku Terhadap Kepuasan Nasabah Pada PT. Bank Sulselbar Kantor Cabang Belopa ". Jurnal Osfprints

Sugiana, Wari. 2018 "Strategi Meningkatkan Kualitas

Pelayanan

Melalui Digitalisasi Produk Perbankan Di Bank Bni 
Syariah Kcp Bulaksumur Yogyakarta”, FEB Islam, IAIN Purwokerto.

Saputri, Intan Dwi. 2020 "Strategi Meningkatkan Kualitas Pelayanan Melalui Digitalisasi Produk Perbankan Pada PT. Bank Mandiri (Persero) Tbk Kantor Cabang Malang Wahid Hasyim", Universitas Muhamaddiyah Malang

Sugiyono.2010. Metode Penelitian Pendidikan Pendekatan Kuantitatif, Kualitatif dan R \& D. Bandung: Alfabeta. 